\title{
THE EFFECT OF REFERRAL AND TREATMENT OF SEVERE PREECLAMPSIA ON MATERNAL DEATH AT SULTAN IMANUDIN GENERAL HOSPITAL PANGKALAN BUN, CENTRAL KALIMANTAN
}

\author{
Hartono Sriwandoko, Ede Surya Darmawan
}

Hospital Administration Department, Faculty of Public Health, Universitas Indonesia

\begin{abstract}
Background: Severe preeclampsia is an obstetric emergency, requiring a rapid appropriate referral and treatment. Emergency obstetrics are still facing three phenomena belated recognizing and deciding. Preeclamsia is also often belated reaching a reference place, and belated getting and adequate treatment. This study aimed to determine the effect of referral and treatment of severe preeclampsia on maternal death at Sultan Imanudin General Hospital Pangkalan Bun, Central Kalimantan.

Subjects and Method: This was retrospective cohort study conducted at Sultan Imanudin Hospital, Pangkalan Bun, Central Kalimantan, from January to December 2017. A sample of 94 pregnant women with preeclamsia was selected for this study by purposive sampling. The dependent variable was maternal death. The independent variables were referring, early treatment, referral travel time, operating room response time, delivery room, delivery time, and delivery, emergency response time, $\mathrm{MgSO}_{4}$, and nifedipine. The data was obtained from medical records and analyzed by Multiple Logistic regression.

Results: The risk of maternal death increased with complicated delivery $(R R=27.66$; $95 \% \mathrm{CI}=3.71$ to $206.26 ; \mathrm{p}=0.001)$, incompetent referal $(\mathrm{RR}=21.80 ; 95 \% \mathrm{CI}=2.70$ to $175.60 ; \mathrm{p}=0.004)$, and late treatment $(\mathrm{RR}=13.62 ; 95 \% \mathrm{CI}=2.25$ to $82.45 ; \mathrm{p}=0.004)$, long referral travel time $(R R=9.99 ; 95 \% \mathrm{CI}=1.76$ to $56.75 ; \mathrm{p}=0.009)$, long operating room response time $(\mathrm{RR}=0.05 ; 95 \% \mathrm{CI}<0.01$ to $0.56 ; \mathrm{p}=0.014)$, and long delivery room response time $(\mathrm{RR}=9.80 ; 95 \% \mathrm{CI}=1.56$ to $61.51 ; \mathrm{p}=0.015)$.

Conclusion: The risk of maternal death increases with complicated delivery, incompetent referal, late treatment, long referral travel time, long operating room response time, and long delivery room response time.
\end{abstract}

Keywords: maternal death, severe preeclamsia, complicated delivery, late treatment.

Correspondence:

Hartono Sriwandoko, Hospital Administration Department, Faculty of Public Health, Universitas Indonesia, Depok, West Java. Email: swandoko@ymail.com. Mobile: o81326182332. 